\title{
Om Sverige, svenskhet och de Andra i samhällsorientering för nyanlända
}

\author{
Kim Silow Kallenberg \& Erika Sigvardsdotter
}

SAMMANDRAG: Samhällsorienteringskurser erbjuds nyanlända flyktingar för att ge dem grundläggande kunskap om Sverige och det svenska samhället. Syftet med Kim Silow Kallenberg och Erika Sigvardsdotters artikel är att analysera de bilder av Sverige, svenskhet och de Andra som framträder i kursernas undervisningsmaterial. Utifrån en narrativ ansats undersöks både berättelser och tystnader i materialet, där det som inte är uttalat förstås som en aspekt av berättelsen om Sverige och svenskheten. Materialet är både informativt och normerande, det beskriver både vad som är vanligt och vad som är önskvärt. Skrivningar om omständigheter där utrikesfödda kan bli förfördelade saknas i hög grad, samtidigt som sammanhang där utrikesfödda skulle kunna diskriminera eller skada någon annan beskrivs utförligt. Materialet kan därför tolkas som att det i första hand utgår från majoritetsbefolkningens perspektiv och behov, trots att det riktar sig till nyanlända.

NYCKELORD: narrativ; logiker; etableringsinsatser för flyktingar; integration; nyliberalism; normer.

PUBLICERINGSHISTORIK: Originalpublicering.

KIM SILOW KALLENBERG är etnolog vid Röda Korsets högskola.

E-POSTADRESS: kim.silow.kallenberg@rkh.se

ERIKA SIGVARDSDOTTER är kulturgeograf vid Röda Korsets högskola.

E-POSTADRESs: erika.sigvardsdotter@rkh.se

FÖRSLAG PÅ KÄLLANGIVELSE:

Silow Kallenberg, Kim \& Erika Sigvardsdotter (2019) "Om Sverige, svenskhet och de Andra i samhällsorientering för nyanlända", i Arkiv. Tidskrift för sambällsanalys, nr II, s. 7I-96.

DOI: https://doi.org/IO.I3068/2000-62I7.II.3

(C) Författarna/Arkiv förlag \& tidskrift 2019 (publicerad 9 december 20I9)

Artikeln distribueras enligt en upphovsrättslicens från Creative Commons:

Erkännande-Ickekommersiell-IngaBearbetningar 3.o Unported, som medger fri ickekommersiell användning och spridning i oförändrat skick så länge källan anges. 
Arkiv. Tidskrift för samhällsanalys är en sakkunniggranskad vetenskaplig tidskrift för samhällsvetenskap och historia. Samtliga artiklar publiceras fritt tillgängliga på:

$$
\text { www.tidskriftenarkiv.se }
$$

Beständig länk, DOI: https://doi.org/IO.I3068/2000-62I7

Den här artikeln finns tillgänglig i följande format:

PDF: via beständig länk, DOI: https://doi.org/IO.I3068/2000-62I7.II.3

TRYCK: ingår i bokutgåva av numret, ISBN: 978 9I 79243333

Grafisk utformning och sidnumrering är identisk i pdf och tryck.

Samtliga artiklar i nr II (2019) nås via beständig länk, DOI: https://doi.org/IO.I3068/2000-62I7.II

Arkiv. Tidskrift för sambällsanalys

ISSN: 2000-6217 (för elektronisk resurs)

ISSN: 2000-6225 (för tryckta nummer)

ges ut av

Stiftelsen Arkiv för främjande och spridning av samhällsvetenskaplig och historisk forskning

genom

Arkiv förlag \& tidskrift

Box 1559

SE-22I OI Lund

BESÖK: L Gråbrödersg 3 c, ipg

TEL: 046-I3 3920

ARKIV FÖRLAG: arkiv@arkiv.nu·www.arkiv.nu

TIDSKRIFTEN ARKIV: red@tidskriftenarkiv.se.www.tidskriftenarkiv.se

ANSVARIg UTGIVARE \& CHEFREDAKTÖR: Sven Hort

Administrativ Redaktör: David Lindberg

Redaktörer: Paavo Bergman, Per Dannefjord, Lisa Kings,

Zhanna Kravchenko, Anna-Maria Sarstrand Marekovic 


\title{
Om Sverige, svenskhet och de Andra i samhällsorientering för nyanlända
}

\author{
KIM SILOW KALLENBERG \\ \& ERIKA SIGVARDSDOTTER
}

I de etableringsinsatser som erbjuds nyanlända flyktingar i Sverige ingår, vid sidan om arbetsmarknadsåtgärder och utbildning i svenska för invandrare (sfi), även samhällsorienteringskurser. Samhällsorienteringen syftar till att ge grundläggande kunskaper om Sverige och det svenska samhället och kan betraktas som en integrationsinsats. Men vad ingår i samhällsorienteringen för nyanlända? Vad lyfts fram som exempel på vilket slags land Sverige är och på vad som ingår i svensk kultur? Vilken information finns inte med och hur kan det förstås? I den här artikeln analyserar vi undervisningsmaterial till samhällsorienteringsutbildningar för nyanlända invandrare i syfte att identifiera och analysera de bilder av Sverige, svenskhet och de Andra som framträder i materialet. Primärt analyserar vi den digitalt tillgängliga läroboken $\mathrm{Om}$ Sverige (20I7) som används vid den här typen av utbildningar i hela landet.

I artikeln tillämpar vi en narrativ ansats för att urskilja vad som sägs - och vad som inte sägs - om Sverige, svenskhet och de Andra i vårt material. Vi kommer i linje med etnologen Georg Drakos (2005) diskutera detta i termer av berättelser och tystnader, där relationen mellan dessa inte betraktas som ett motsatsförhållande. Snarare förstås tystnader - det som inte är uttalat - som en aspekt av berättelsen om Sverige och svenskheten i det analyserade materialet (jfr Drakos 2005, s. I2). Den narrativa ansatsen kompletteras med ett diskursteoretiskt logikperspektiv (Glynos \& Howarth 2007) samt med en diskussion utifrån begrepp som 
"disciplin", "styrningskonst" (gouvernementalité, Foucault 1988, I997; Lemke 20II) och "nyliberalism" (Wacquant 2009).

Inledningsvis ger vi en bakgrund till insatserna för etableringen av nyanlända generellt, och till samhällsorienteringen specifikt, samt diskuterar den politiska kontext inom vilken samhällsorienteringen äger rum. Därefter redogör vi för sådan tidigare forskning som är relevant för att förstå empirin och de frågor artikeln vill besvara. Innan vi går vidare med undersökningen kommer först ett avsnitt som utförligare presenterar vårt analyserade material. Själva analysen är indelad i två huvudsakliga områden: det som sägs respektive det som inte sägs. I detta följer vi den narrativa analysens fokus på berättelser och tystnader som lika viktiga delar i ett narrativ. Artikeln avslutas med en diskussion där vi sammanfattar våra mest centrala slutsatser.

\section{Etableringsuppdraget, samhällsorienteringen och dess politiska kontext}

Nyanlända, som är målgruppen för etableringsinsatserna, inklusive samhällsorienteringen, är personer som ”är mottag[na] i en kommun och har beviljats uppehållstillstånd för bosättning på grund av flyktingskäl eller andra skyddsskäl”. I Även anhöriga till dessa personer räknas till gruppen nyanlända. "Anländandet" i ordet "nyanländ" handlar alltså inte om att en person fysiskt anlänt till svenskt territorium, utan om att ha blivit bosatt (och folkbokförd) i en kommun där personen i fråga ska delta $\mathrm{i}$ etableringsinsatser. Asylsökande som ännu inte fått besked om huruvida de får stanna i Sverige har i denna mening ännu inte "anlänt" till Sverige. Personer benämns som nyanlända under tiden de omfattas av lagen om etableringsinsatser, det vill säga två till tre år. Invandrare som kommit till Sverige av andra skäl än skyddsskäl - exempelvis arbetskraftsinvandrare och EU- eller EES-medborgare - benämns inte som nyanlända och erbjuds inte etableringsinsatser så som samhällsorientering.

Etableringsuppdraget, som sedan etableringslagen (SFS 2010:197) trädde i kraft ligger under Arbetsförmedlingens ansvar, syftar till att

I. Från https://www.lansstyrelsen.se/download/I8.840e7car63033co6Ifi8dd7/I52606807 8964/Ordf\%C3\%B6rklaringar.pdf (hämtat I5 oktober 2019). 
nyanlända snabbt ska lära sig det svenska språket, komma i arbete, och därmed klara sin egen försörjning. Insatserna som ska främja detta består av språkundervisning (sfi), individanpassade arbetsmarknadsåtgärder (praktik, validering av utbildning etc.), och en samhällsorienterande utbildning. Denna lagstiftning föregicks av en rad utredningar och utvärderingar som konstaterade att introduktionen av nyanlända i Sverige, som tidigare främst varit kommunernas ansvar, var ineffektiv och för långsam. Avsikten i propositionen om etableringslagen var att etableringen av nyanlända skulle inlemmas i den så kallade arbetslinjen och att integrationspolitiken skulle ta steget från "omhändertagande till ansvarstagande" (prop. 2009/ıO:60, s. 24). ${ }^{2}$ Argumentet var att omsorg och omhändertagande är passiviserande, och att de nyanlända i stället själva ska ta mer ansvar för sin integration i det svenska arbets- och samhällslivet. Marie Carlson menar att med dagens fokus på "arbetslinjen" har sfi-utbildningen "alltmer kommit att ses som ett arbetsmarknadsinstrument" (Carlson 2013, s. 836).

Dessa utgångspunkter avspeglas också i reformerna av den utbildning om Sverige som land och samhälle som ska erbjudas nyanlända. I samband med etableringslagen 2010 beslutades att utbildningen skulle kallas samhällsorientering. Tidigare varierade benämningarna men det var vanligt att tala om samhällsinformation. Ansvaret för att ge denna information låg helt och hållet på kommunerna. Ordet orientering antyder att det handlar om att lära sig att navigera i sitt nya sammanhang, snarare än att bara förses med information om det. I detta ligger den nya reformen i linje med en ökad förväntan om eget ansvarstagande från de nyanlända själva (jfr Silow Kallenberg \& Sigvardsdotter 20I8; Carlson 2013, s. 826).

I förordningen om samhällsorientering för vissa nyanlända invandrare (Fm 20IO:I) framgår att varje nyanländ ska erbjudas en samhällsorientering om minst 60 timmar. Detta är den lägre gränsen för kursernas omfattning men de kan sedan vara utformade på olika sätt och vara olika långa. I Stockholm stads övergripande information om samhälls-

2. Sedan januari 2018 regleras etableringsinsatserna övergripande i den nya lagen om ansvar för etableringsinsatser för vissa nyanlända invandrare (SFS 2017:584). Detta innebär i dagsläget inga direkta förändringar för etableringsinsatsernas innehåll. 
orientering nämns kurser som omfattar 72 timmar, men det finns också folkhögskolor som ger kurser på heltid i sex månader. Dessa längre utbildningar ges i samarbete med Folkbildningsrådet och prioriterar deltagare med kort tidigare utbildning. Det är kommunernas ansvar att erbjuda samhällsorientering och att utforma kursplan och upplägg. Det kommunala ansvaret möjliggör lokala variationer i upplägget, dock med utgångspunkt i de nationella direktiven i förordningstexten (Fm 20IO:I). Inte sällan köps tjänsten in av privata aktörer.

I de utredningar som föregick den nuvarande samhällsorienteringens utformning diskuterades innehåll och fokus för kurserna. Utmaningen identifierades som att lyckas beskriva Sverige på ett realistiskt sätt, så som det faktiskt fungerar:

Det är en konkret utmaning för alla försök att innehållsbestämma samhällsorienteringen att beskrivningen av det svenska nuläget inte får bli för idealistisk. Den bild som ges av Sverige måste i detta avseende illustrera hur det faktiskt fungerar, genom att pedagogiskt uppmärksamma problem som kan uppstå när grundläggande värden ska förverkligas i praktiken. En god samhällsorientering handlar om att få möjlighet att reflektera över dessa frågor och komma till insikt om sin egen roll och sina egna åsikter och förhållningssätt i sammanhanget. Utan denna insikt kan man knappast aktivt ta ställning till och bli delaktig i samhället (SOU 20I0:I6, s. 6I).

Citatet visar hur kärnan i samhällsorienteringens verksamhet ska vara förmedlingen av och diskussioner om "grundläggande värden". Genom att orientera sig mot svenska normer och värderingar ska nya medborgare bli delaktiga i det svenska samhället. Citatet belyser också det som framstår som den största svårigheten, att beskriva Sverige på ett ödmjukt sätt, eftersom det mesta är bra här. Man anar en svensk självbild av att vara moraliskt högtstående i relation till andra nationaliteter, etniciteter eller kulturer (jfr Danielsson Malmros 20I2, s. II).

Samhällsorientering är en i högsta grad politiserad fråga som har diskuterats sedan 1960-talet utifrån grundidén om att nya medborgare behöver lära sig om sitt nya land för att få en bra start. Under senare tid har det politiska klimatet hårdnat i migrations- och integrationsfrågor, och under valrörelsen inför 2018 års val blev samhällsorienteringen en central del av debatten om den "misslyckade integrationen". I decem- 
ber 2017 skrev arbetsmarknads- och etableringsminister Ylva Johansson en debattartikel på DN Debatt där hon framhöll vikten av att nyanlända fick lära sig svenska värderingar i samhällsorienteringsutbildningen. ${ }^{3}$ Johansson varnade för att vi skulle "göra oss ängsliga inför att skapa dialog om vilka värderingar vårt samhälle vilar på idag”, och därmed undvika dessa frågor i samhällsorienteringen. Sedan dess har flera andra debattartiklar publicerats. ${ }^{4}$ Ofta ligger tyngdpunkten i debatten på just normer och värderingar, snarare än de andra former av kunskaper som också lärs ut och diskuteras i samhällsorienteringen. Moderaterna har också vid flera tillfällen återkommit till samhällsorientering som en nyckel till integration och har föreslagit hårdare krav på nyanlända att lära sig svenska, ta sig in på arbetsmarknaden och lära sig om det svenska samhället. Ett av Moderaternas förslag i denna riktning har efterfrågat "integrationsplikt" för nyanlända som kräver utvidgade samhällsorienteringskurser med tillhörande test. ${ }^{5}$

I Europa har man på flera håll också talat om behovet av att skapa social sammanhållning mellan nya och gamla medborgare genom att främja nationell gemenskap och en gemensam värdegrund (NTG-asyl $\&$ integration 2007). Dessa förslag kommer ofta upp i samband med våldsamma terrordåd, eller upplopp som förklaras utifrån argument om "misslyckad integration", "social exkludering" och "utanförskap". Även om "misslyckad integration" antyder ett ansvar hos det mottagande samhället som inte uppfyllts, är stora delar av denna debatt antingen utan aktörskap (t.ex. om "social exkludering", jfr Fairclough 200o), eller placerar en stor del av ansvaret hos den exkluderade ("utanförskap", jfr Davidsson 20IO).

I de europeiska diskussionerna om att bygga en gemensam värdegrund blir det tydligt att utanförskap eller avsaknaden av gemenskap

3. Se https://www.dn.se/debatt/stark-orientering-om-svenska-varderingar-for-nyanlanda/ (hämtat Is oktober 20I9).

4. Se t.ex. http://www.dagensjuridik.se/2018/o2/regeringen-vill-undervisa-nyanlanda-isvenska-normer-ska-underlatta-etableringen (hämtat Is oktober 20I9) och https://www. svd.se/vansterns-normkritik-har-underminerat-samhallet (hämtat I5 oktober 20I9).

5. Se https://moderaterna.se/m-integrationsplikt-nyanlanda (hämtat 2I februari 2018) och http:/www.sydostran.se/karlskrona/m-vill-ha-integrationsplikt-i-karlskrona/ (hämtat 2I februari 20I8). 
hos vissa grupper endast till viss del handlar om social rättvisa och individuella möjligheter. Viktigare för denna typ av politik är i stället föreställningar om nationell säkerhet och hur denna säkerhet bör uppnås (NTG-asyl \& integration 2007, s. 7). Enligt ett sådant perspektiv betraktas utanförskap och segregation som ett potentiellt hot och målet blir assimileringen av nya medborgare. Premissen för diskussionerna om en gemensam värdegrund kopplad till förebyggandet av våldsdåd är ett antagande om att skillnader i normer och värderingar är en av orsakerna till sådana dåd. Det är med andra ord just olikheterna människor emellan som antas vara problemet, och en bidragande orsak till våld.

\section{Teoretisk och metodologisk ram}

Vi har redan konstaterat att samhällsorienteringen är ett i hög grad politiserat område, och att de nya etableringsinsatserna ska ses som en del av arbetslinjen. Dessa insikter präglar vår analys och det avgränsade kursmaterial som vi analyserar behöver därför kontextualiseras genom en förståelse av det politiska sammanhang inom vilket det har en plats och en roll. Här utgår vi ifrån teorier om det nyliberala samhället eftersom nyliberalism är en politisk strömning som haft ett väsentligt inflytande på integrations- och utbildningsdiskurser sedan åtminstone 2000-talet (Carlson 2013, s. 834).

Nyliberalism omfattar bland annat ett ökat krav på aktivitet och aktivering. Detta går igen i många sammanhang och speglar sig i det övergripande skiftet från välfärdssamhälle till arbetssamhälle, vilket brukar benämnas som workfare på engelska (Wacquant 2009, s. 6; Rueda 2015, s. 299) och handlar om hur välfärdsrättigheter blir alltmer villkorade med krav på motprestationer i form av arbete eller arbetssökande. Krav på aktivering kan också skönjas på olika håll i integrationspolitiken där nyanlända förväntas vara sysselsatta med till exempel språkundervisning och arbete eller praktik (jfr Osman I999, s. I22).

Sociologen Loïc Wacquant skriver om nyliberalism som bestående av dels ett ideologiskt projekt, dels av politiska praktiker som hyllar det individuella ansvaret på alla områden i samhället (2009, s. I). Nyliberalismen kan i sin tur kopplas till begreppet "styrningskonst" (fra. gouver- 
nementalité, eng. governmentality) som beskriver en form av makt där statsapparaten, genom lagar, förordningar, institutioner och byråkratier, finns närvarande i människors vardag och i deras mentalitet (Börjesson \& Rehn 2009, s. 49). Denna maktform skiljer sig från traditionell auktoritet och fysiskt tvång genom att den framför allt agerar via frihet och har människors välmående som mål. Styrningskonst bygger på självdisciplinering och egenmakt, och är därmed en maktform som passar det nyliberala tänkandet. När en person väljer "fel" kan dock mer tvingande maktformer ta vid. Att fokus inom styrningskonst och nyliberalism ligger på att människor själva ska ta ansvar och välja innebär med andra ord att dessa val inte kan göras fritt, utan bara att så länge "rätt" val görs så är makten osynlig och "vänlig" (Bartholdsson 2008).

Inom denna övergripande ram har vi använt oss av specifika analytiska verktyg. Vår huvudsakliga analysmodell är en narrativ ansats hämtad från etnologen Georg Drakos (2005). I denna utgör det som sägs och det som inte sägs - berättelser och tystnader - lika viktiga delar av ett narrativ. Här är det vad som sägs och inte sägs om Sverige, svenskarna och de Andra som står i fokus. Drakos menar att det kan finnas många olika anledningar till att vissa ämnen präglas av tystnad och inte blir föremål för berättelser. Det kan till exempel handla om att den som berättar strategiskt undviker att tala om känsliga eller svårgripbara ämnen, eller om att vissa ämnen inte framstår som meningsfulla eller relevanta att tala om (Drakos 2005, s. I2). Anna Johansson menar i sin tur att ju mer risk för konflikt som föreligger, desto större anledning att välja att inte tala om ett ämne (Johansson 2005, s. 269). Drakos kopplar sitt resonemang om berättelser och tystnader vidare till Foucaults diskursbegrepp, där diskurser är vad som "kvalificerar och diskvalificerar, legitimerar och ogiltigförklarar olika sätt att tala om verkligheten" (Drakos 2005, s. 13). Enskilda berättelser och tystnader är enligt detta perspektiv alltså kopplade till, och beroende av, större meningsstrukturer. En sådan större meningsstruktur kan i det här fallet vara "svenskhetslogiker" som konstituerar hur det är och ska vara i Sverige, samt hur du ska vara som svensk.

För att förstå sådana "logiker" har Jason Glynos och David Howarths (2007) diskursteoretiska logikperspektiv varit centralt i analysen. En "logik" kan generellt förstås som de syften, regler och förgivettaganden 
som gör en praktik, eller en kontextuell uppsättning av praktiker, möjlig och begriplig (Glynos \& Howarth 2007, s. 15). Annorlunda uttryckt kan en logik förstås som "ett system av regler som påverkar vad som är möjligt i en viss kontext" (Lundgren 2012, s. 59f.). Den senare definitionen öppnar upp för en bredare förståelse av vad som kan studeras när man fokuserar på logiker. Glynos och Howarth skriver explicit om ett fokus på praktiker men deras analytiska begrepp har använts även för att förstå intervjumaterial (se t.ex. Silow Kallenberg 20I6; Lindberg 20I5; Andersson 20I6) och för att analysera text (se t.ex. Andersson 20I6; Remling 20I7). I den här artikeln undersöker vi vad som är möjligt inom etableringsinsatserna. Att fokusera på logiker skulle kunna beskrivas som ett sätt att studera diskurser på mikronivå, eftersom båda begreppen syftar på kluster av mening. Logiker befinner sig dock på en underordnad nivå jämfört med diskursers övergripande karaktär. Vi menar att vi genom att kvalitativt undersöka vissa aspekter av ett tydligt avgränsat sammanhang, och samtidigt bära med oss en förståelse av hur detta sammanhang hänger ihop med större processer, kan öka vår kunskap om hur diskurser skapas och omskapas (Silow Kallenberg 20I6, s. 44).

Gemensamt för dessa teoretiska verktyg är att de kan betraktas som kritiska perspektiv. Detta ska inte förstås som att vår intention är att kritisera det material vi studerar, utan snarare som att vi vill pröva och problematisera de idéer och perspektiv som uttrycks däri. En kritisk ansats utesluter inte heller att vi samtidigt kan ha förståelse för att det är en svår uppgift att författa ett material som det vi har studerat. Detta är vi fullt medvetna om, men vår ambition är att synliggöra de diskursiva strömningar, eller "meningserbjudanden" som texten enligt vår tolkning uttrycker (jfr Carlson 2013).

Det forskningssammanhang som den här artikeln i första hand hör hemma i är den forskning om internationell migration och etniska relationer (IMER) som fokuserat utbildningskontexter generellt och samhällsorientering specifikt. Marie Carlson har i flera texter analyserat läromedel och läromedlens kontext, särskilt med fokus på sfi (Carlson 2002, 2013, 20I7; Carlson \& Kanci 20I7). Carlson har bland annat visat på förändringar över tid för sfi, som till exempel lett till ett ökat fokus på att nyanlända snabbt ska komma i arbete och en större tonvikt på eget ansvar. 
Elisabeth Elmeroth (2008) har studerat "den etniska maktordning" som hon menar präglar utbildningssfären i Sverige. Elmeroth har till exempel visat hur deltagarnas tidigare erfarenheter osynliggörs i utbildningar som riktar sig till vuxna invandrare (2008, s. 107). Hon menar att många av de utbildningsprojekt som riktar sig till denna målgrupp tycks syfta till en tredubbel omskolning där deltagarna förväntas byta yrke, språk och värdegrund (Elmeroth 2008, s. I07; jfr Carlson 2013, s. 833). Elmeroth visar dessutom hur utbildningar för vuxna invandrare sker i lokaler "där invandrare och etniska svenskar skiljs åt" vilket innebär att integration här och nu inte är vad som åsyftas (2008, s. I07). Det är snarare en framtida integration som är målet med dessa utbildningar - till exempel sfi och samhällsorienteringskurser.

Lisbeth Eriksson (2010) har intervjuat lärare som undervisar på samhällsorienteringskurser och beskriver hur de betonar vikten av att lära ut svenska normer, traditioner och sociala koder. Lärarnas utgångspunkt är, skriver Eriksson, att de nyanlända som går kurserna har andra normsystem, och för att bli accepterad i Sverige måste man bete sig som majoriteten. Afrah Abdulla gör en liknande tolkning utifrån deltagande observation i samhällsorienteringskurser (Abdulla 20I7; Abdulla \& Risenfors 2013). Etablering handlar i hög grad om att forma vuxna nyanlända till "goda medborgare" - vilket innebär en medborgare som är självständig, sekulariserad, jämlik, ärlig och laglydig (Abdulla 20I7, s. 68ff.). I detta "medborgarskap" ingår även att arbeta, enligt Abdullas analys.

Magnus Dahlstedt (2009) har studerat policydokument som diskuterar hur "invandrarföräldrar" ska göras delaktiga i sina barns skolgång och fungera som samarbetspartner till skolan. Dahlstedt visar att dokumenten präglas av en nyliberal retorik, där begrepp som egenansvar och aktivitet blir mått på ett gott föräldraskap (2009, s. 202). Vidare visar han att det framför allt är föräldrar med migrantbakgrund i multietniska områden som görs till föremål för diskussioner om delaktighet i barnens skolgång, utifrån en föreställning om att denna grupp av föräldrar inte automatiskt är delaktiga eller vill vara det. Det goda medborgarskapet, där föräldraskapet ingår som en aspekt, är enligt Dahlstedt definierat utifrån en vit medelklassnorm, vilket gör de föräldrar som faller utanför den normen till "de Andra" (2009, s. 203). 
I Sverige finns inga särskilda test kopplade till samhällsorienteringen som påverkar möjligheten att uppnå fullvärdigt medborgarskap. Detta är dock fallet på andra håll i Europa och västvärlden, och som tidigare nämnts finns en politisk vilja och opinion att införa "integrationsplikt" även i Sverige. Ines Michalowski (2OII) har studerat medborgarskapstest i fem olika länder i Europa och Nordamerika. Michalowski gör en innehållsanalys av de frågor som används i testen och visar att frågorna dels handlar om faktakunskaper om de olika ländernas historia och politik, dels om normkunskaper om vad som är vanligt, brukligt och moraliskt rätt i det aktuella landet (Michalowski 20II, s. 753). Den första kategorin frågor kopplar Michalowski samman med liberala idéer och den senare kategorin med en restriktivare eller mer konservativ politik. Hon menar att faktakunskaper om till exempel politiskt styre eller historia är neutrala kunskaper, medan normer och värderingar inte är det. Michalowski menar att medborgarskapstest i sig själva varken är tecken på en restriktiv migrationspolitik eller på en mer liberal sådan, vilket tidigare forskning hävdat (20II, s. 765). I stället visar hon hur länder med en restriktiv politik - vad gäller till exempel hur många invandrare som tas emot och hur många som får stanna - kan använda liberalare medborgarskapstest. Michalowski menar att liberalare test är sådana där innehållet inte pekar i en riktning av att nya medborgare ska assimileras och infogas i en likriktad värdegemenskap (20II, s. 765). Tvärtom visar hon att strängare test ibland används i länder där mottagandet är generösare.

\section{Materialet som analyseras - innehåll och tilltal}

Det material som analyseras i den här artikeln är primärt kursboken $O m$ Sverige $(2017)^{6}$. Boken finns tillgänglig online på flera språk och är just läromedel för utbildningar i samhällsorientering. Boken ger en bred översikt över Sverige och det svenska samhället och tar upp en mängd olika

6. Se https://www.informationsverige.se/sv/jag-har-fatt-uppehallstillstand/samhallsorientering/boken-om-sverige/. Den första upplagan av boken togs fram av Göteborgs stad 2010 och har sedan reviderats flera gånger. Den upplaga vi analyserar här är den femte som gavs ut 20I7. Vid denna artikels publicering är boken inne på sin sjunde upplaga. Siduppgifter utan annan angiven källa i den följande framställningen hänvisar till $\mathrm{Om}$ Sverige (2017). 
teman, till exempel arbetsmarknad, högtider, hälsa och familjeliv. Boken är ca tvåhundra sidor lång och är indelad i åtta kapitel med följande rubriker: "I. Att komma till Sverige", "2. Att bo i Sverige", "3. Att försörja sig och utvecklas i Sverige", "4. Individens rättigheter och skyldigheter", "5. Att bilda familj och leva med barn i Sverige", "6. Att påverka i Sverige", "7. Att vårda sin hälsa i Sverige" och "8. Att åldras i Sverige". Dessa ämnesområden är fastslagna i förordningen (Fm 20IO:I) och överensstämmer i stort med de som föreslogs ingå i samhällsorienteringen i den statliga utredning som låg till grund för den nuvarande lagen och organisationen av samhällsorienteringen (SOU 20I0:I6, s. 59).

Kapitlen kan sägas följa en tänkt livsloppskronologi som börjar med att anlända till Sverige och som fortsätter med att bosätta sig här, bilda familj och arbeta, för att slutligen åldras. Efter varje kapitel följer ett antal diskussionsfrågor med anknytning till kapitlets övergripande tema. Generellt kan man säga att det i materialet finns en pendling mellan det mycket konkreta (hit går du om du blivit sjuk, så här gör du när du ska gå på arbetsintervju, så här firar vi i Sverige olika högtider etc.) och det abstrakta (idéer, värderingar, normer etc.). Det kan också uttryckas som att det finns en rörelse mellan det relativt neutrala till det mer laddade (jfr Michalowski 20II, s. 753ff.).

Tilltalet i kursmaterialet är genomgående personligt, i du-form. ”Tänk på att skriva kontrakt när du ska hyra i andra hand" (s. 5I), ”Du som har barn under åtta år ...” (s. I52), ”En betalningsanmärkning är ett tecken på att du inte har skött dina betalningar" (s. 68), "Att jobba svart betyder att du inte betalar någon skatt på det du tjänar” (s. 95). Kring vissa teman som kan antas ligga längre ifrån nyanländas omedelbara vardag går dock tilltalet över i ett mer opersonligt tredjepersonstilltal: "När man startar en förening ska man ha en styrelse" (s. IIO). Tredjepersonstilltalet används också i vissa sammanhang som kan antas ligga nära en del nyanländas vardag, som här i ett stycke som handlar om föräldraskap.

Att komma till ett nytt land är en stor förändring för både vuxna och barn. Ibland kan barn ha lättare att komma in i det nya samhället än vuxna. Vuxna kan därför bli beroende av sina barn i kontakterna med samhället. Det kan leda till ändrade roller i familjen och innebära att det läggs ett för stort ansvar på barn. Barn ska till exempel inte tolka åt sina föräldrar i kontakten med förskolan, skolan, myndigheter eller sjukvården. 
Det är därför viktigt att föräldrar får kunskap om det samhälle familjen har kommit till och förstår att barnets nya vardag och livsmiljö också blir en del av deras person. Då finns förutsättningar för dem att bli starka och tydliga föräldrar så att de kan skapa en trygg miljö för sina barn (s. 139).

Här kan vi läsa att "vuxna" kan bli beroende av sina barn i olika samhälleliga kontakter och att "föräldrar" behöver få kunskap om det nya samhället. I mitten av stycket uttrycks i passiv form "att det läggs ett för stort ansvar på barn”. Alla nyanlända är visserligen inte föräldrar, men av allt att döma är inte detta skälet till det förändrade tilltalet. Snarare tycks det mer distanserade tilltalet handla om att undvika spänning i en potentiellt laddad fråga. Detta mönster upprepas i andra potentiellt laddade frågor vilket vi kommer att visa nedan.

I citatet ovan framträder också indirekt en motivering för samhällsorienteringen som sådan i och med att kunskapen om det nya samhället är vad som sägs utgöra grunden för det trygga föräldraskap som här förespråkas (jfr Dahlstedt 2009). Svenskt föräldraskap lyfts här mer eller mindre indirekt fram som en norm.

\section{Det som sägs om Sverige - explicitgörandet av svenska normer}

För alla de teman som kursboken innehåller gäller att mycket av informationen förmedlas i form av väldigt konkreta beskrivningar av hur man gör i Sverige. Detta förmedlas främst genom att olika beteenden och fenomen beskrivs som vanliga, alternativt hur "många" gör eller brukar göra. Exempel på detta är formuleringar som: "I Sverige har många människor semester i juli och augusti [...] i augusti är det vanligt att gå på kräftskiva” (s. 30), "de flesta personer har ett bankkonto" (s. 67), "många arbetsgivare förväntar sig att du ska hälsa på dem genom att ta i hand" (s. 89), "i Sverige och Norden är det vanligt att vara sambo" (s. 136), "Många ungdomar har en eller flera kärleksrelationer när de växer upp" (s. I40). Det "vanliga" som många, eller de flesta sägs göra handlar alltså både om praktiska saker, men också teman med mer eller mindre tydliga normativa budskap om exempelvis handhälsning eller sexuella relationer utanför äktenskap. 


\section{Demokrati som svensk norm}

Ett centralt och genomgående tema i materialet är demokrati, och detta är något som särskilt adresseras i avsnittet "Skolan och demokrati”. Här finns flera exempel där skolan beskrivs som en arena för att fostra nya medborgare i demokratiska värderingar (jfr Elmeroth 2008; Carlson \& Kanci 20I7; Osman 2006).

I den svenska skolan pratar man mycket om demokrati. Ett av målen i skolan är att eleverna ska växa upp till vuxna som är delaktiga och tar ansvar för det gemensamma samhället (s. I49).

Det demokratiska samhället definieras här som ett samhälle där vuxna tar ansvar för det gemensamma samhället genom att vara delaktiga i det. Det är i skolan som demokrati lärs ut. Demokrati förstås alltså här som något som barn ska tränas i under skolgången för att de ska kunna använda sig av den, och utöva den, som vuxna. Det här kan läsas som ett antagande om att demokrati är något en person bör ha med sig från barndomen för att kunna bli en god demokratisk vuxen. Utifrån ett sådant antagande kan individer som inte är uppväxta i Sverige med den demokratiskt orienterade skolgången förstås som potentiella problem (jfr Osman 2006; Osman 1999). I den här kontexten görs demokrati till något unikt svenskt som kan vara svårt att tillägna sig i vuxen ålder. Den Andre definieras i detta inte bara som annorlunda jämfört med majoritetsbefolkningen, utan även som ett problem som bottnar i föreställda kulturella skillnader (jfr Osman 1999, s. I22). I en europeisk jämförelse kan man se att detta med att göra demokrati och mänskliga rättigheter till något specifikt för den egna nationen inte är något som Sverige är ensamt om. Det görs på flera håll i Europa (NTG-asyl \& integration 2007, s. 29).

\section{Föräldraskap på svenska}

Föräldraskap är ytterligare ett tema som får mycket utrymme i undervisningsmaterialet $O m$ Sverige. Det är också ett område som tidigare studier har visat är centralt för integrationsåtgärder (se t.ex. Dahlstedt 2009; Abdulla 20I7), kanske eftersom föräldraskap är så intimt förknippat med jämställdhet och med den svenska självbilden av att vara bäst på jäm- 
ställdhet (Carlson 20I7). Marie Carlson beskriver hur jämställdhet i sfiundervisningen uppfattas som en viktig svensk värdering (2017, s. 59).

Även när materialet tar upp föräldraskap explicitgörs normer i termer av vad som är vanligt: "Det är vanligt att den andra föräldern till det väntade barnet är med på besök och möten. Det är också vanligt att den andra föräldern är med på förlossningen” (s. I38). Ett mer utförligt exempel ser ut så här:

Det är vanligt att både kvinnor och män tar ledigt från arbete eller studier för att vara hemma med sina barn. Men det är fortfarande fler kvinnor än män som är hemma med barn. För att uppmuntra en jämnare fördelning av föräldraförsäkringen finns det reserverade dagar som inte går att överlåta till den andra vårdnadshavaren (s. I5I).

I citatet ovan framträder normbegreppets dubbla betydelse där en norm kan vara både det som är vanligt förekommande och det som är önskvärt eller eftersträvansvärt (jfr Hacking 1990, s. I60; Hörnfeldt 2009, s. 15). Vi får till en början veta att det är vanligt att både män och kvinnor stannar hemma med sina barn för att sedan få information om att det är ännu lite vanligare för kvinnor att göra så. Det är också tydligt i citatet att en jämnare fördelning av vem som tar ut dagarna i föräldraförsäkringen är något som anses önskvärt.

Magnus Dahlstedt (2009, s. 202) har i sin studie om föräldrar med migrantbakgrund och deras relation till svensk skola visat att det förväntade föräldraskapet präglas av en nyliberal retorik, där begrepp som egenansvar och aktivitet blir mått på ett gott föräldraskap. Detta ligger också i linje med hur normerna om föräldraskap generellt har förändrats i Sverige. ${ }^{7}$ Att man i det material som vi har analyserat diskuterar delaktighet vid till exempel förlossningar som vanligt (och därmed önskvärt), har direkta paralleller till Dahlstedts analys om föräldrar med migrantbakgrund och deras delaktighet i sina barns skolgång. Dahlstedt menar att detta sker utifrån en föreställning om att denna grupp av föräldrar inte automatiskt är delaktiga eller vill vara det. Detta är anledningen till

7. Ett exempel på denna rörelse är hur de tidigare föräldrautbildningarna ersatts av vad som i dag heter föräldraskapsstöd. Detta skifte speglar den förändrade synen på föräldraskap i Sverige - tidigare skulle goda föräldrar utbildas av experter, nu ska den kompetenta och autonoma föräldern stödjas i sitt föräldraskap (se Lundqvist 2015). 
att frågan om delaktighet över huvud taget aktualiseras i relation till personer med migrantbakgrund.

Vad som är vanligt och typiskt i Sverige har en framträdande roll i samhällsorienteringsmaterialets beskrivningar. Det finns alltså en tydlig normativ ansats, något som kan förstås med hjälp av begreppet "sociala logiker". I Jason Glynos och David Howarths logikperspektiv används begreppet för att beskriva sådant som diskursivt konstrueras som vanligt och beskrivs som typiskt (Glynos \& Howarth 2007, s. 154). Det vanliga och typiska är alltid kontextuellt, både geografiskt och historiskt, och implicit i diskursteoretiska perspektiv finns alltid en förståelse av vår verklighet som präglad av kontingens (Glynos \& Howarth 2007, s. I09), alltså att den vid en annan tidpunkt eller på en annan plats skulle kunna vara annorlunda beskaffad. I och med detta tänker man sig inte att det finns någon given essens eller kärna i verkligheten eller i våra sociala relationer och identiteter. Givet andra förutsättningar skulle allting kunna se annorlunda ut. I samhällsorienteringsmaterialet blir det också tydligt hur dessa "sociala svenskhetslogiker", som vi skulle kunna kalla dem, uppstår relationellt i kontrast till föreställningar om hur det ser ut på andra platser eller i andra "kulturer".

Ordet "vanligt" signalerar förväntningar på hur den som tar emot den här informationen ska bete sig i relation till föräldrautbildning, möten på mödravårdscentralen och vid förlossningen. "Vanligt" kan alltså läsas som en neutral beskrivning av en rådande ordning, av hur "folk gör mest", men också som ett slags pockande imperativ som uppmanar till ett visst agerande. Detta kan uttryckas som att materialet uttrycker - och är medskapare av - normer kopplade till graviditet och föräldraskap. Genom att dessa normer beskrivs i ett material med titeln "Om Sverige" blir de inte föräldraskapsnormer mer generellt, utan de kan förstås som svenska normer för graviditet och föräldraskap. Beskrivningarna av hur "vi gör här" kan därför förstås som byggande på en implicit förståelse av att "Andra” gör på andra sätt. Det vanliga beskrivs så utförligt just för att det antas vara sådant som inte är självklart utanför den svenska kontexten. De nyanlända mer eller mindre förutsätts tänka och göra annorlunda, vilket motiverar att de ges så tydliga instruktioner för hur det ska vara här (jfr Dahlstedt 2009; Osman I999, s. I22). De tydliga 
instruktionerna ges kanske också för att de svenska logikerna - exempelvis hur man är en god förälder - förstås som de enda rätta. Detta visar i sin tur på kontingensen i svenskhetslogikerna, att det som beskrivs som självklart och givet också kan upplevas vara hotat i mötet med det annorlunda. Carlson har beskrivit hur den "etniskt svenska kvinnan" utgör sinnebilden för en modern och frigjord kvinna - till skillnad från "invandrarkvinnan" som i stället antas vara präglad av andra negativt laddade egenskaper som till exempel passivitet, underordning och traditionsbundenhet (Carlson 20I7, s. 63). Utifrån en sådan föreställning kan det som förstås som svenska jämställdhetsnormer uppfattas vara hotade när Andra kvinnor kommer hit.

Tydliga instruktioner för hur de nyanlända förväntas agera ges även i relation till barnaga - en annan fråga som också rör föräldraskap. Texten, som tar upp att aga är förbjudet i Sverige, förklarar vad som är våld och vad som inte är våld:

Anti-agalagen säger att det är förbjudet att använda fysiskt och psykiskt våld mot barn. Fysiskt våld är alla former av våld mot kroppen. Också lätta slag, att dra i håret och nypa är fysiskt våld.

Däremot får du självklart rycka bort ett barn från något som är farligt, till exempel en het spis, ett öppet fönster eller något annat som kan skada barnet.

Psykiskt våld kan vara att hota, skrämma, frysa ut eller låsa in ett barn. Psykiskt våld kan skada barnets självkänsla och utveckling lika mycket som fysiskt våld (s. I40).

Här ges mycket tydliga exempel på vad som är och vad som inte är aga. Det som är aga presenteras med ett mer distanserat tilltal medan det mellanliggande stycket om vad som inte är aga - vad man får göra - återvänder till du-tilltalet. Att det finns lagstiftning som förbjuder aga är å ena sidan neutral kunskap som är viktig att känna till, å andra sidan kan temat läsas som ett explicitgörande av svenska normer och värderingar. Att förbudet mot barnaga skrivs fram så tydligt signalerar en förståelse av mottagarna av materialet som potentiella barnmisshandlare, vilket bygger på idéer om kulturellt och socialt avstånd (jfr Osman I999, s. I22).

Det svenska kan å ena sidan förstås som ett partikulärt mått, å andra sidan också läsas som ett universellt mått på hur det borde vara. Flera forskare har diskuterat hur det finns en självbild av Sverige som ett anti- 
rasistiskt föregångsland, och i relation till detta har bland andra Ylva Habel (20I2) talat om en svensk exceptionalism, där Sverige förstås som bättre än andra länder. Habel menar att Sverige reproducerar bilden av sig själv som ett raslöst och tolerant land som berörts mindre av koloniala processer än andra länder i omvärlden (20I2, s. 67). Detta kan läsas som ett exempel på en nationell självbild präglad av idéer om moralisk överhöghet som kanske också kan överföras även till ett område som föräldraskap. Även Joan Forbes, Elisabet Öhrn och Gaby Weiner (20II) har diskuterat hur den svenska jämställdheten görs till en slags kulturell markör som framställer Sverige som ett land som kommit långt i sin utveckling och som är särskilt tolerant och reformvänligt i jämförelse med andra länder (jfr Carlson 20I7, s. 59; Björk 20I7).

\section{Individualism kontra kollektivism}

En del av det som sägs om Sverige i materialet uttrycks explicit genom att kontrastera hur det är här mot hur det är i andra länder:

I Sverige har äldre som behöver stöd och hjälp enligt lagen rätt till detta från samhället. Medan det i andra länder kan vara vanligare att familj och släktingar tar hand om äldre, är det i Sverige ofta samhället som står för det stödet. Familjen är ofta fortfarande delaktig i den äldres liv (s. 209).

Det här är ett exempel på när det partikulära betonas, det vill säga sådant som är specifikt för Sverige i jämförelse med andra länder. Här är det samhällets roll $\mathrm{i}$ att vårda de äldre som lyfts fram som specifikt i jämförelse med länder där familj och släktingar har det primära ansvaret. Det betonas dock också att detta inte innebär att familjen inte är delaktig i sina äldre släktingars liv. Det kan uttryckas som att man gör skillnad på ett juridiskt eller ekonomiskt ansvar, och ett socialt, emotionellt eller kulturellt ansvar. Betoningen som görs på att familjen fortsätter att vara en del av den äldre släktingens liv kan också läsas som att man i materialet talar emot en nidbild av Sverige där de äldre lämnas åt sitt öde och där sammanhållningen i familjer är svag.

Vad är en familj? Svaret på frågan är olika i olika kulturer och samhällen. I vissa delar av världen ses släkten eller gruppen man tillhör som en del av familjen. I Sverige räknas oftast bara föräldrar, syskon och barn som familj. Vad som är en 
individ kan också se olika ut i olika kulturer och samhällen. Två olika sätt att se på individer är ett individualistiskt synsätt och ett kollektivistiskt synsätt (s. I24).

Lite längre ner på samma sida skrivs också explicit ut att Sverige på många sätt är ett individualistiskt samhälle. Skillnaden mellan individ och kollektiv återkommer sedan flera gånger i det aktuella kapitlet som handlar om individens rättigheter och skyldigheter, till exempel i relation till det laddade området hedersvåld.

Våld inom familjen och våld mot kvinnor finns i alla länder och i alla kulturer. Våld som handlar om heder är våld mot någon som bryter mot familjens eller släktens normer och traditioner. [...] Hedersrelaterat våld är vanligast i kollektivistiska samhällen eller där män ges mycket mer makt än kvinnor (s. I28).

Här görs det kollektivistiska synsättet till något farligt och hotfullt, och samtidigt även till något osvenskt. På andra håll i materialet diskuteras ojämställdhet mellan könen även som ett problem i majoritetsbefolkningen i Sverige, att män ges mer makt än kvinnor även bland infödda svenskar. Genom att använda begreppet hedersvåld förläggs problem med våld i nära relationer utanför majoritetsbefolkningen. Genom att säga att det är vanligast i kollektivistiska samhällen, när Sverige beskrivs som individualistiskt, förläggs problemet till "osvenska" sammanhang, inom eller utanför landets gränser (jfr Carlson 20I7, s. 55).

\section{Det som inte sägs om Sverige - implicita normer för svenskhet}

Betoningen på demokrati och demokratiska värderingar går, som vi diskuterat ovan, igen i hela materialet, och blir en framträdande del av den svenskhet som konstrueras i kursboken Om Sverige. Demokrati innebär att människor ska ha samma rättigheter och skyldigheter, och i materialet är kön en maktordning och potentiell ojämlikhetsfaktor som ofta lyfts fram explicit. Ett exempel på detta är när det i materialet står: "Flickor och pojkar ska ha samma chanser i skolan” (s. I49). Att det slås fast att kön inte ska vara avgörande för hur det går i skolan eller för hur någon behandlas där visar på att detta inte är självklart för läsaren. Men hur ska vi då förstå att andra potentiellt ojämlikhetsskapande faktorer inte 
skrivs fram: till exempel etnicitet, hudfärg och religion? Ska det förstås som tecken på att dessa faktorer inte förstås som ojämlikhetsskapande kategoriseringar, eller handlar det om något annat?

I föregående avsnitt diskuterade vi exempel på när samhällsorienteringsmaterialet tog upp företeelser och förhållningssätt som beskrivs som vanliga, och kanske därmed även önskvärda i den svenska kontexten. Dessa betraktar vi som exempel på när Sverige och det svenska relativt konkret beskrivs och slås fast. I detta avsnitt ska vi i stället undersöka tystnader - det som inte sägs om Sverige och det svenska - för att visa hur det outsagda kan tala sitt tydliga språk om det som är norm och det som avviker i konstruktionen av svenskhet (jfr Drakos 2005, s. 26).

\section{Jämställdhet och jämlikhet som räknas}

Sverige är på många sätt ett jämställt land. Cirka 80 procent av alla kvinnor i Sverige mellan 20 och 64 år arbetar utanför hemmet, vilket är en hög andel i jämförelse med många andra länder. Men det finns brister i jämställdheten på arbetsmarknaden. Kvinnor som arbetar inom samma yrken som män har oftast lägre lön trots att de gör samma jobb som män. Det finns färre kvinnor än män i företagens ledningar. Forskning visar också att det är skillnad på mäns och kvinnors möjligheter att kunna kombinera arbete och familjeliv (s. 76).

Det som utdraget ur materialet ovan beskriver är ett välkänt förhållande av ojämställdhet mellan könen som råder på den svenska arbetsmarknaden. Trots detta beskrivs Sverige som ett på många sätt jämställt land, kanske specifikt i relation till de länder där den tänkta läsaren av materialet kommer ifrån. Jämställdhet förstås här dels som något relationellt snarare än ett faktiskt tillstånd, dels som det normala tillståndet varifrån ojämställdhet är ett undantag. Detta är i sig intressant, men det ur utlandsföddas perspektiv minst lika intressanta förhållandet av ojämlikhet som baserar sig på födelseland (svensk eller utländsk bakgrund), på arbetsmarknaden eller i andra sammanhang, återfinns inte alls i materialet. När det gäller arbetslöshet och etablering på arbetsmarknaden beskrivs situationen i Sverige så här:

Ungefär hälften av alla människor i Sverige har ett arbete med lön. Arbetslösheten är ungefär 6,5 procent. Arbetslösheten för ungdomar mellan I5-24 år är högre och ligger på cirka 16,4 procent (s. 9I). 
I relation till den arbetsmarknad på vilken de nyanlända ska försörja sig är arbetslöshet en högst påtaglig och relevant aspekt (se t.ex. Osman 2006, s. 207). Utrikes födda, den grupp som materialet vänder sig till, som till och med har en högre andel arbetslösa än ungdomar, 22,0 procent i augusti 2017 enligt Arbetsförmedlingen, ${ }^{8}$ förblir osynlig. Precis som i beskrivningen av jämställdhet och ojämställdhet på den svenska arbetsmarknaden råder här en tystnad om de utrikesföddas situation.

Den enda aspekt där statistik om utlandsföddas under- eller överrepresentation faktiskt kommenteras i kursmaterialet rör valdeltagande: "Valdeltagandet är också lägre bland utrikes födda. Intresset för att rösta ökar ofta ju längre tid en person har varit bosatt i Sverige" (s. I73f.). Valdeltagande, till skillnad från arbetslöshet eller jämlikhet, läggs fram som en fråga om intresse och individens val. Det är de utrikes födda som inte är så intresserade av att rösta (men blir det efter hand), snarare än att det finns strukturella eller andra hinder. Med andra ord är det de utlandsfödda som individer som görs till problem, som på grund av sitt ointresse eller sin passivitet väljer att inte rösta. Ali Osman har i en studie om vuxenutbildning för utrikesfödda vuxna visat att just utrikesfödda som passiva är en vanlig problembeskrivning (I999, s. I22; jfr Dahlstedt 2009). Detta kan också förstås som något som ligger i linje med en nyliberal ordning, där ansvaret för framgångar och motgångar i hög utsträckning läggs på individer och inte i första hand på yttre faktorer (jfr Wacquant 2009, s. I).

\section{Diskriminering}

Liknande mönster återfinns i de delar av materialet som handlar om diskriminering. Materialets fokus ligger i dessa frågor på kön och sexuell läggning, med utförliga exempel och kringinformation. När det gäller diskriminering på etnisk grund finns ett kort stycke text med generell information, samt en något mer utförlig text rörande diskriminering på religiös grund. Med utgångspunkten att den tänkta läsaren ofta är av annan etnisk bakgrund än den majoritetssvenska - och således skulle vara betjänt av att få kunskap om denna typ av diskriminering med lika

8. Se https://arbetsformedlingen.se/om-oss/press/pressmeddelanden?id=852EDF28667 68042 (hämtat Is oktober 2019). 
tydliga exempel och fyllig information som rörande diskriminering på grund av kön och sexuell läggning - är frånvaron av sådan information anmärkningsvärd. Materialet tycks snarast riktat mot en läsare som riskerar att diskriminera andra, och som därmed behöver informeras om vilka normer som gäller i Sverige, än någon som riskerar att bli diskriminerad och behöver veta sina rättigheter (kvinnor, barn och hbtqpersoner undantagna). Återigen är den tolkning som ligger närmast till hands att utgångspunkten i materialet är en majoritetssvensk position, trots att det officiellt riktar sig till nyanlända med en annan bakgrund än majoritetssvensk.

Utifrån dessa exempel på tystnader i materialet kan det vara på sin plats att reflektera kring vad som görs till ett problem, och varför. Vårt perspektiv är att ett problem inte är ett problem i sig, utan konstrueras som ett problem för någon (jfr Bacchi 2008). Det som görs till problem i samhällsorienteringsmaterialet är framför allt sådant som kan utgöra problem för majoritetsbefolkningen (exempelvis ojämställdhet mellan könen), eller sådant som de nyanlända själva föreställs vara skapare av (homofobi, hedersvåld, aga). Problem som kan antas vara mer aktuella för de nyanlända (etnisk diskriminering, islamofobi) lyfts inte fram på samma sätt. Marie Carlson har i en studie som bland annat analyserar sfi-läromedel visat att dessa sällan innehåller texter som problematiserar arbetsmarknads- och integrationsfrågor. Inte heller tar dessa läromedel upp diskriminering till diskussion (Carlson 20I7, s. 67).

Tystnaderna om till exempel utrikesföddas överrepresentation $\mathrm{i}$ arbetslöshetsstatistiken kan tolkas som att man gärna undviker att beskriva fenomen där den tilltänkta läsaren kan identifiera sig som potentiellt förfördelad eller diskriminerad. Eller som att diskriminering på etnisk grund inte berörs eftersom det inte är ett problem för majoritetsbefolkningen. Det är denna senare tolkning som utifrån vår läsning av materialet framstår som mest rimlig. Genom att inte skriva fram diskriminering på etnisk grund som ett problem i Sverige görs också Sverige till en vit och enhetlig nation, och att vara svensk likställs med att vara vit.

Daphne Arbouz (20I2) har diskuterat det hon menar är en tydlig svensk norm av färgblind antirasism (jfr Habel 20I2; Hübinette m.f. 20I2, s. I4). Genom att anamma ett färgblint ideal, och mena sig inte 
se människors färg eller ras, menar Arbouz att de privilegier som följer av att kunna passera som vit osynliggörs (2012, s. 38). Det färgblinda idealet osynliggör även det faktum att det enbart är vita som betraktas som svenska, medan icke-vita kopplas samman med det icke-svenska och främmande (Arbouz 20I2, s. 38).

\section{Sammanfattande diskussion}

I den här artikeln har vi analyserat material som används i samhällsorienteringen för nyanlända, en del av de integrationsfrämjande insatser som erbjuds inom ramen för etableringslagen. Syftet var att identifiera och analysera de bilder av Sverige, svenskhet och de Andra som framträder i materialet, genom att analysera vad som sägs och inte sägs. Vi har inte tittat närmare på den praktiska utformningen eller på hur materialet används. Det vi har undersökt är de dokument och det utbildningsmaterial som är gemensamt nationellt för samhällsorienteringen. Vi menar att detta kan ge en relativt god bild av dessa kursers utgångspunkter.

Vi har visat att det som framför allt sägs om Sverige är att det är ett demokratiskt och jämställt land (jfr Carlson 2017). Sverige beskrivs även som ett individualistiskt land, vilket i huvudsak beskrivs i positiva ordalag då kollektivistiska samhällen som kontrast förknippas med företeelser som hedersvåld och traditionella genusordningar. Bland det uttalade finns tydliga beskrivningar av vad som är "vanligt", vilket fungerar både som en neutral beskrivning av sakernas tillstånd och som ett imperativ för handling. Normer utgör både det vanliga och det önskvärda (Hörnfeldt 2009, s. I5; jfr Hacking 1990) och beskrivningar av normer kan därför fungera som mallar som individen förväntas orientera sig mot och anpassa sig till.

I formuleringar om vad som är "vanligt" och vad "många gör" här finns inga uttalade krav, utan normerna är i stället tänkta att fungera genom att individen disciplinerar sig själv till att följa dem (jfr Foucault 1997). De explicita kraven finns inte i kursmaterialet utan snarare i de politiska diskussioner som omgärdar det. Kursmaterialet befinner sig i dialog med det omgivande samhället och måste alltså förstås i sin politiska kontext för att bli begripligt. 
Att man nu mer entydigt talar om samhällsorientering snarare än samhällsinformation tyder på att deltagarna förväntas vara mer än passiva mottagare av förmedlad kunskap. Att fokusera på individens ansvar kan å ena sidan förstås som ett bemyndigande, å andra sidan tenderar detta skifte att göra enskilda ansvariga för strukturella faktorer. Detta ligger i linje med de individualiseringsprocesser som följer på en nyliberal diskurs. Individen har ansvar för att orientera sig mot det svenska samhället, något som också i sig kan betraktas som en del av "svenskblivandet". Orientering som begrepp kan givetvis användas och förstås på andra sätt. Ett exempel som skiljer sig från tolkningen vi gör här är Sara Ahmeds resonemang om orientering som att "hitta vägen" och att "hitta hem" (Ahmed 2006, s. 7).

Individualisering för de nyanlända handlar alltså knappast om någon högre grad av valfrihet. Att orientera sig mot det svenska är i det närmaste att betrakta som ett villkor för att nyanlända ska inkluderas, oavsett om så kallade medborgarskapstest implementeras eller inte (se t.ex. Michalowski 20II). Det går att fråga sig hur fri valfriheten är för grupper som inte tillhör majoritetsbefolkningen, och vi kan konstatera att politiska diskussioner om exempelvis integrationsplikt hämtar sina argument i idéer som snarare är kopplade till en stark stat än till nyliberala ideal. Valfrihet är ett ideal som de nyanlända förväntas omfamna, men vad de sedan kan göra med sin valfrihet är i själva verket kraftigt begränsat.

Vi har även visat är att det finns mycket som materialet inte säger om Sverige. Det hade varit rimligt och relevant att informera om svårigheter som kan drabba den som har en bakgrund i ett annat land, men där möts läsaren av tystnad. Generellt är materialet tyst när det gäller områden där utrikesfödda skulle kunna bli förfördelade, samtidigt som man skriver utförligt om sammanhang där utrikesfödda antas vara i position att kunna diskriminera eller skada någon annan. Detta tolkar vi som att materialet i första hand utgår från majoritetsbefolkningens perspektiv och behov, trots att det officiellt riktar sig till nyanlända. Det tycks alltså som att den orientering nyanlända får inte primärt handlar om att de ska få verktyg att hitta vägen och hitta hem i det nya samhället (jfr Ahmed 2006, s. 7), utan att det rör sig om en orientering med syftet att de nyanlända inte ska störa ordningen. 


\section{Referenser}

\section{Litteratur}

Abdulla, Afrah 2017. Readiness or resistance? Newly arrived adult migrants' experiences, meaning making, and learning in Sweden. Linköping: Linköpings universitet

Abdulla, Afrah och Signild Risenfors 2013. "Kursen för samhällsorientering för nyanlända - mobilisering och integration för deltagare", i Eriksson, Lisbeth, Gunilla Nilsson och Lars A. Svensson (red.), Gemenskaper. Socialpedagogiska perspektiv. Göteborg: Daidalos

Ahmed, Sara 2006. Queer phenomenology. Orientations, objects, others. Durham: Duke University Press

Andersson, Pernilla 20I6. The responsible business person. Studies of business education for sustainability. Huddinge: Södertörns högskola

Arbouz, Daphne 20I2. "Vad betyder det att inte känna sig hemma där man är född och uppvuxen? Om mellanförskap i dagens Sverige", i Hübinette, Tobias, Helena Hörnfeldt, Fataneh Farahani och René León Rosales (red.), Om ras och vithet i det samtida Sverige. Botkyrka: Mångkulturellt centrum

Bacchi, Carol Lee 2008. Women, policy and politics. The construction of policy problems. London: Sage

Bartholdsson, Åsa 2008. Den vänliga maktutövningens regim. Om normalitet och makt $i$ skolan. Stockholm: Liber

Björk, Sofia 2017. Gender and emotions in family care. Understanding masculinity and gender equality in Sweden. Göteborg: Göteborgs universitet

Börjesson, Mats och Alf Rehn 2009. Makt. Stockholm: Liber

Carlson, Marie 2002. Svenska för invandrare - brygga eller gräns? Syn på kunskap och lärande inom sfi-undervisningen. Göteborg: Göteborgs universitet

Carlson, Marie 2013. "Sfi och sfi-läromedel i tid och rum - Föreställningar, politik och tidsanda”, i Hyltenstam, Kenneth och Inger Lindberg (red.), Svenska som andraspråk. I forskning, undervisning och sambälle. Lund: Studentlitteratur

Carlson, Marie 20I7. ' Invandrarkvinna', 'svensk' och 'jämställd'. Om kategoriell komplexitet och (o)synliggörande i utbildning, politik och arbete", Tidskrift för genusvetenskap 38, 3, s. 53-76

URL: http://ojs.ub.gu.se/ojs/index.php/tgv/article/view/4277 (I5 oktober 2019)

Carlson, Marie och Tuba Kanci 2017. "The nationalised and gendered citizen in a global world - examples from textbooks, policy and steering documents in Turkey and Sweden", Gender and Education 29, 3, s. 313-33I DoI: https://doi.org/I0.I080/09540253.20I6.II439I7

Dahlstedt, Magnus 2009. "Parental governmentality: involving 'immigrant parents' in Swedish schools", British Journal of Sociology of Education 30, 2, s. 193-205 DOI: https://doi.org/IO.IO80/OI425690802700289

Danielsson Malmros, Ingmarie 20I2. Det var en gång ett land ... Berättelser om svenskhet $i$ historieböcker och i elevers föreställningsvärldar. Höör: Agerings Bokförlag 
Davidsson, Tobias 20I0. "Utanförskapelsen. En diskursanalys av hur begreppet utanförskap artikulerades i den svenska riksdagsdebatten 2003-2006", Socialvetenskaplig tidskrift $\mathrm{17}$, 2, s. 149-169

URL: https://journals.lub.lu.se/svt/article/view/I5705 (I5 oktober 2019)

Drakos, Georg 2005. Berättelsen i sjukdomens värld. Att leva med hiv/aids som anhörig $i$ Sverige och Grekland. Eslöv: B. Östlings bokförlag Symposion

Elmeroth, Elisabeth 2008. Etnisk maktordning i skola och sambälle. Lund: Studentlitteratur

Eriksson, Lisbeth 20I0. "Swedish way of teaching citizenship to immigrants - popular adult education as a social pedagogical activity", i Eriksson, Lisbeth och Thomas Winman (red.), Learning to fly. Social pedagogy in a contemporary society. Göteborg: Daidalos

Fairclough, Norman 2000. New labour, new language? London: Routledge

Forbes, Joan, Elisabet Öhrn och Gaby Weiner 20II. "Slippage and/or symbolism: gender, policy and educational governance in Scotland and Sweden", Gender and Education 23, 6, s. 76I-776

DOI: https://doi.org/I0.1080/09540253.2010.527830

Foucault, Michel 1988. "Politics and reason", i Kritzman, Lawrence D. (red.), Michel Foucault. Politics, philisophy, culture. Interviews and other writings 1977-1984. New York: Routledge

Foucault, Michel 1997. "On the government of the living", i Rabinow, Paul (red.), Essential works of Foucault, 1954-1984. Vol. I, Ethics. Subjectivity and truth. New York: New Press

Glynos, Jason och David Howarth 2007. Logics of critical explanation in social and political theory. New York: Routledge

Habel, Ylva 20I2. "Rörelser och schatteringar inom kritiska vithetsstudier", i Hübinette, Tobias, Helena Hörnfeldt, Fataneh Farahani och René León Rosales (red.), Om ras och vithet $i$ det samtida Sverige. Botkyrka: Mångkulturellt centrum

Hacking, Ian 1990. The taming of chance. Cambridge: Cambridge University Press

Hübinette, Tobias, Helena Hörnfeldt, Fataneh Farahani och René León Rosales 2012. "Om ras och vithet i det samtida Sverige. Inledning", i Hübinette, Tobias, Helena Hörnfeldt, Fataneh Farahani och René León Rosales (red.), Om ras och vithet i det samtida Sverige. Botkyrka: Mångkulturellt centrum

Hörnfeldt, Helena 2009. Prima barn, helt u.a. Normalisering och utvecklingstänkande i svensk barnhälsovård 1923-2007. Göteborg: Makadam förlag

Johansson, Anna 2005. Narrativ teori och metod. Lund: Studentlitteratur

Lemke, Thomas 20II. Foucault, governmentality, and critique. Boulder: Paradigm

Lindberg, Jens 20I5. Orsak: våldtäkt. Om våldtagna män i medicinsk praktik. Stockholm: Carlssons

Lundgren, Anna Sofia 20I2. "Logikperspektivet - ett försök till analysmetod", Kulturella perspektiv 3-4, s. 59-67

Lundqvist, Åsa 20I5. "Parenting support in Sweden: New policies in old settings", Social Policy and Society I4, 4, s. 657-668

DoI: https://doi.org/IO.IOI7/SI474746415000238 
Michalowski, Ines 20II. "Required to assimilate? The content of citizenship tests in five countries", Citizenship Studies 15, 6-7, s. 749-768 DOI: https://doi.org/I0.1080/13621025.2011.600116

Osman, Ali 1999. The "strangers" among us. The social construction of identity in adult education. Linköping: Linköpings universitet

Osman, Ali 2006. "Integrerande 'praktiker' som arena för normalisering och disciplinering av utlandsfödda", i Gunnarsson, Ewa, Anders Neergaard och Arne Nilsson (red.), Kors och tvärs. Intersektionalitet och makt i storstadens arbetsliv. Stockholm: Normal förlag

Remling, Elise 2017. "Logics, assumptions and genre chains: a framework for poststructuralist policy analysis", Critical Discourse Studies I5, I, s. I-I8 DoI: https://doi.org/Io.I080/I7405904.2017.1382382

Rueda, David 2015. "The state of the welfare state: Unemployment, labor market policy, and inequality in the age of workfare", Comparative Politics 47, 3, s. 296-3I4 DOI: https://doi.org/I0.5129/o0I041515814709275

Silow Kallenberg, Kim 2016. Gränsland. Svensk ungdomsvård mellan vård och straff. Huddinge: Södertörns högskola

Silow Kallenberg, Kim och Erika Sigvardsdotter 20I8. "Från omhändertagande till ansvarstagande. Nyliberal hälsa i etableringen av nyanlända", Kulturella perspektiv $3-4$, s. 46-56

Wacquant, Loïc 2009. Punishing the poor. The neoliberal government of social insecurity. Durham: Duke University Press

\section{Rapporter och statliga utredningar}

Förordningsmotiv 20Iо:I. Förordning om samhällsorientering för vissa nyanlända invandrare NTG-asyl \& integration 2007. Europeisk medborgarkunskap - för alla? Om sambällsinformation och gemensam värdegrund $i$ ett mångkulturellt Europa. Stockholm: NTG-asyl $\&$ integration

Proposition 2009/I0:60. Nyanlända invandrares arbetsmarknadsetablering - egenansvar med professionellt stöd

SOU 20IO:I6. Sverige för nyanlända. Värden, välfärdsstat, vardagsliv. Delbetänkande av Utredningen om sambällsorientering för nyanlända invandrare. Stockholm: Arbetsmarknadsdepartementet

\section{Skriftlig källa}

Om Sverige. Samhällsorientering på svenska 2017. Femte upplagan. Göteborg: Göteborgs stad 
Hur blir man medborgare och vad betyder det att vara medborgare? Medborgarskapet kan vara den efterlängtade slutdestinationen för en lång och mödosam flykt, men det kan också vara startpunkten för en svårdefinierbar integrationsprocess. Antologin VÄGAR TILL MEDBORGARSKAP handlar om

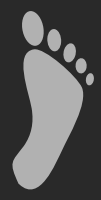

medborgarskapets villkor och förutsättningar i Sverige och världen idag.

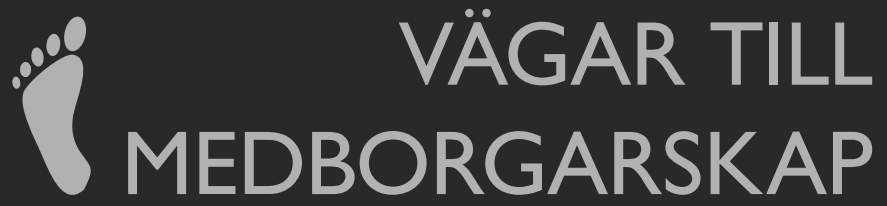

Pieter Bevelander, i Christian Fernández \& Anders Hellström (red)

Arkiv förlag, danskt band, 173 sidor »Läs mer om boken på www.arkiv.nu巛 


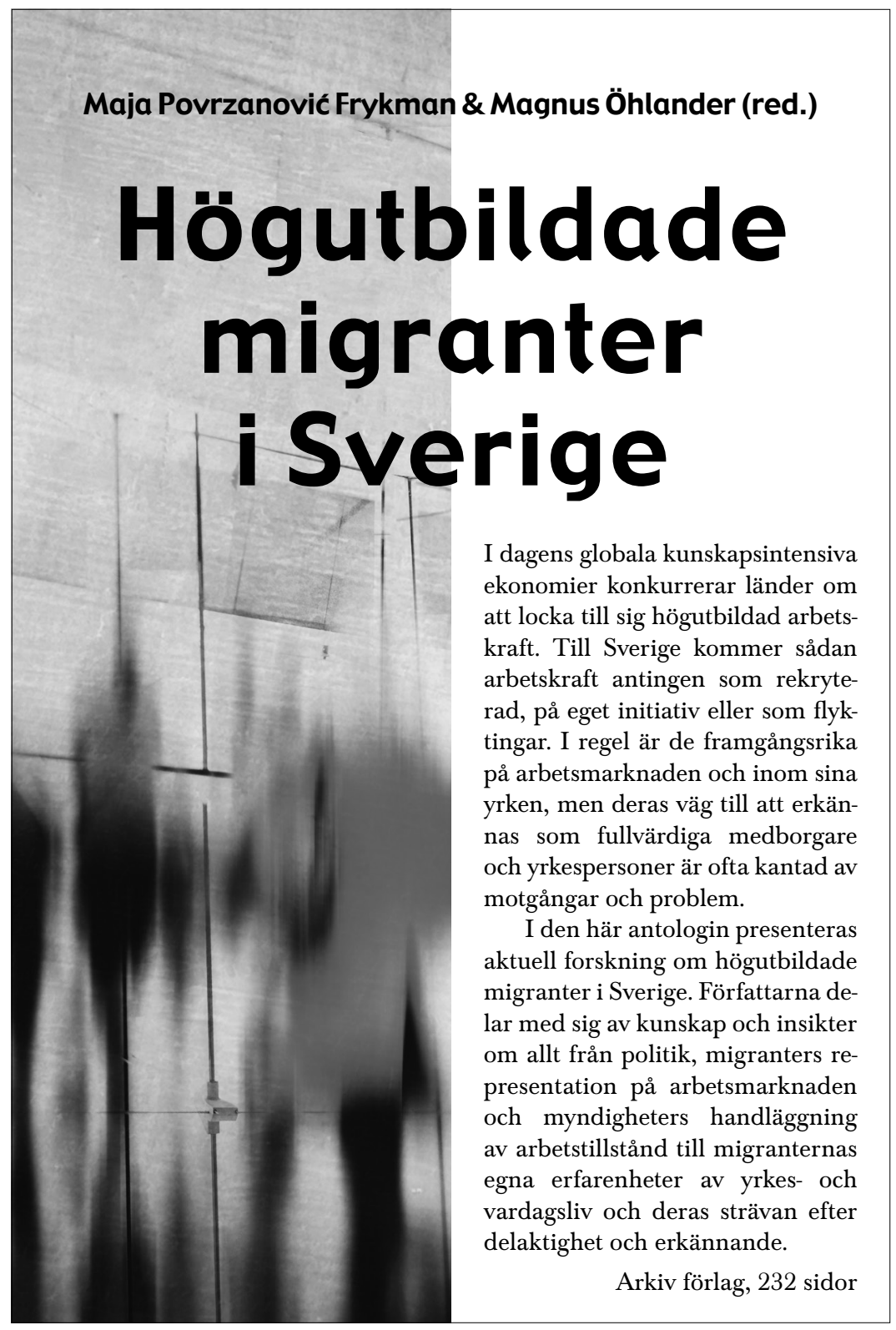

\section{»Läs mer om boken på www.arkiv.nu«}

